\title{
BIOACTIVE COMPOUNDS IN WINES PRODUCED IN A NEW AREA FOR VITIVINICULTURE IN BRAZIL
}

\author{
COMPOSTOS BIOATIVOS EM VINHOS PRODUZIDOS EM NOVA ÁREA DE \\ VITIVINICULTURA NO BRASIL
}

\section{Ana Carolina VILAS BOAS ${ }^{1}$; Rita de Cássia Mirela Resende NASSUR ${ }^{2 *}$; Paôla de Castro HENRIQUE ${ }^{1}$; Giuliano Elias PEREIRA ${ }^{3}$; Luiz Carlos de Oliveira LIMA ${ }^{1}$}

1. Federal University of Lavras, Food Science Department, Lavras, MG, Brazil; 2. Bahia State University, Department of Technology and Social Sciences, Juazeiro, BA, Brazil. ritarnassur@hotmail.com; 3. Embrapa Grape and Wine, Bento Gonçalves, RS, Brazil.

\begin{abstract}
Wines are known for its high content of bioactive compounds that can be influenced by the region and climate where the grapes are produced. New regions of production are normally developed using techniques and standards for other traditional regions, but is important to characterize the wine profile, which is different according to the terroir, and can be important for future geographic indications. The aim of this study was to evaluate color, antioxidant activity, anthocyanin content and phenolic compounds profile in wines produced in Minas Gerais State, Brazil. Wines were produced in different wineries of the same region using the varieties Syrah, Merlot, Cabernet Sauvignon, Cabernet Franc (red), Chardonnay and Sauvignon Blanc (white) and Syrah (rose), from municipalities of Cordislândia, Boa Esperança and Três Corações, located in the south of Minas Gerais State, Brazil. Wines produced in Minas Gerais State presented contents of t-resveratrol, total phenolics, anthocyanins, flavonols, flavanols and phenolic acids consistent to the contents observed in wines from traditional regions of production. However, the terroir and the grape variety can result in a differentiation of compounds observed in wines. Syrah red wines produced in Boa Esperança stood out with higher amounts of anthocyanins $\left(24.29 \mathrm{mg} \mathrm{L}^{-1}\right)$, phenolic acids $\left(123,19 \mathrm{mg} \mathrm{L}^{-1}\right)$ and flavonols (35.55 $\left.\mathrm{mg} \mathrm{L}^{-1}\right)$, when compared to wines from the same variety from other municipalities and other evaluated red wines. Sauvignon Blanc wines from Boa Esperança presented higher contents of phenolic acids and total flavonols, when compared to wines of the same variety produced in Cordislândia. Chardonay wines presented higher total phenolics content, when compared to ohther evaluated white wines. Rose wine produced in the South of Minas Gerais presented the phenolic acids content of $36,33 \mathrm{mg} \mathrm{L}^{-1}$ and total flavonols content of $29,7 \mathrm{mg} \mathrm{L}^{-1}$. The highest antioxidant activity using the DPPH method, (\% of free radicals scavenging - FRS) was observed for Syrah wines from Três Corações, (75.37\%), but not different from Cabernet Sauvignon wines from Cordislândia (72.50\%), values that can be correlated with the largest content of phenolics observed in wines as phenolic compounds (3009 $\mathrm{mg}$ $\left.\mathrm{L}^{-1}\right)$. No differences were observed in the contents of the antioxidant activity of white wines. This results indicate that the studied wines present the necessary nutritional and beneficial characteristics to compete in the supply of bioactive compounds during consumption, when compared to wines produced in traditional and different regions in Brazil and other countries.
\end{abstract}

KEYWORDS: Vitis vinifera. Bioactive compounds. Resveratrol. Quality. Brazilian wines.

\section{INTRODUCTION}

Grapes and grape-products deserves special attention for its numerous health benefits, such as inhibiting cancer cells growth, as in the colon, breast and thyroid (SAHPAZIDOU et al, 2014; MAZUÉ et al, 2014.), preventing cervical cancer (Chen, Liu AND ZHENG et al., 2014), presenting antiinflammatory effects (DECENDIT et al., 2013), improving cardiovascular oxidation (HORt et al., 2012) and acting in a reduction of low density lipoproteins (LDL) and increasing high density lipoproteins (HDL) (EVANS et al., 2014).
Minas Gerais State is not a traditionally known producer of grapes and wines, having different soil and climatic conditions when compared to the major producing regions in Brazil, such as the Rio Grande do Sul State and The São Francisco River Valley. Thus, the evaluation of bioactive compounds in wines produced in the South of Minas Gerais State is extremely important to provide to growers and consumers the information regarding the quality of the product of the region. It is also important to know the potential of wines produced according to the reverse cycle technique, which allows the harvest of grapes during 
winter, period without rain incidence, different from the summer period that is used in the South of the country.

Phenolic compounds have pronounced antioxidant activity and are widely present in wines. Recent studies with resveratrol (CHEN et al, 2014; BRESCIANI et al, 2014), proanthocyanidins (FERNÁNDEZ IGLESIAS et al, 2014), rutin (CHOI et al, 2013), among others, show the beneficial action of these compounds in the body. Phenolic compounds can be divided into two groups: flavonoids and no flavonoids, both with low molecular weight compounds, being secondary metabolites present in fruits and vegetables (VOLP et al., 2008).

Among the flavonols, quercetin, kaempferol and myricetin are possibly the best known. In the class of flavanols, are present the catechins and epicatechins, observed mainly in grape seeds, which are the major phenolic compounds responsible for wines taste and astringency (ABE et al., 2007). The biosynthesis and accumulation of anthocyanins are affected by many factors, such as variety, light, and moisture. Moisture plays a crucial role in the biosynthesis of anthocyanins in grape fruit. The anthocyanin compounds in wines are mainly derived from grape berries. Therefore, there is a correlation of the individual anthocyanin contents between grape berries and wines (JU et al., 2019).

The characterization of fine wines from Minas Gerais, specially from the southern part of the State, is a research field that remains unexplored, with no reports of typicality, phenolic content and functional potential of the products. In this context, there is a need for studies that presents this approach, contributing to the implementation and consolidation of the wine production in this region. The objective of this study was to evaluate the antioxidant activity, phenolic profile and anthocyanins content in different wines produced in the south of Minas Gerais State, Brazil.

\section{MATERIAL AND METHODS}

The wines were produced in different wineries in the southern part of Minas Gerais State, Brazil and after bottling, were evaluated at the Federal University of Lavras - UFLA, Brazil. Red wines from grapes of the varieties Syrah, Merlot, Cabernet Sauvignon and Cabernet Franc, white wines from grapes Chardonnay and Sauvignon Blanc and rosé wines from the Syrah variety were evaluated. The wines were produced in wineries located at the municipalities of Cordislândia, Boa Esperança and Três Corações, MG, being the following treatments: STBE (Syrah Red Wine from Boa Esperança), STTC (Syrah Red Wine from Três Corações), STCO (Syrah Red Wine from Cordislândia), MECO (Merlot Red Wine from Cordislândia), CSCO (Cabernet Sauvignon Red Wine from Cordislândia) and CFCO (Cabernet Franc Red Wine from Cordislândia); Whites: SBBE (Sauvignon Blanc from Boa Esperança), SBCO (Sauvignon Blanc from Cordislândia) and CHCO (Chardonnay from Cordislândia); Rosé: SRBE (Syrah Rose From Boa Esperança).

To color of the wines were evaluated using a Minolta colorimeter CR 400 model by searching the $\mathrm{L}^{*}$ coordinate, measuring the lightness or brightness of the sample, ranging from black (0) to white (100). The phenolic compounds were obtained according to the colorimetric method developed by Singleton and Rossi (1965), using the Folin-Ciocalteu reagent, in a solution with a concentration of $10 \% \quad(\mathrm{v} / \mathrm{v})$. The extraction procedure involved sequential steps of centrifugation and filtration to obtain a better extraction of phenolic compounds as described in Larrauri, Saura-Calixto and Rupérez (1997). The absorbance values obtained in the test at $765 \mathrm{~nm}$ were compared with a calibration curve obtained for gallic acid, and results were expressed in $\mathrm{mg} \mathrm{L}^{-1}$ of gallic acid equivalents (GAE).

The anthocyanins analysis was performed according to the differential $\mathrm{pH}$ method proposed by Giusti and Wrolstad (2001). Wine samples were homogenized in $\mathrm{KCl}$ buffer $(0.025 \mathrm{M}, \mathrm{pH}=1.0)$ and $\mathrm{CH}_{3} \mathrm{COONa}(0.4 \mathrm{M}, \mathrm{pH}=4.5)$ and the readings were performed at $520 \mathrm{~nm}$ and $700 \mathrm{~nm}$ in a spectrophotometer. The pigment concentration in the wines was expressed as equivalents of cyanidin3-glucoside in $\mathrm{mg} \mathrm{L}^{-1}$.

The phenolic compounds were determined by HPLC (WATERS, model e2695 Aliance), equipped with a quaternary solvent pump and automatic injector, coupled with DAD and fluorescence detection (FD), according to the methodology described by Natividade et al. (2013). The data collection and analysis were carried in October using the Empower ${ }^{\mathrm{TM}} 2$ software (Milford, USA). In the DAD, the detection of compounds was Performed at $220 \mathrm{~nm}$ for gallic acid (LOD $=0: 07$ $\left.m g \mathrm{~L}^{-1} \mathrm{R}^{2}=0.998\right)$, (_) - gallate epicatechin (LOD = 0:07 mg L $\left.\mathrm{m}^{-1} \mathrm{R}^{2}=0.991\right)\left(\_\right)$- epigalocatechin (LOD $\left.=0: 19 \mathrm{mg} \mathrm{L}^{-1} \mathrm{R}^{2}=0.999\right)$ and procyanidin $\mathrm{B} 1$ (LOD $\left.=0: 03 \mathrm{mg} \mathrm{L}^{-1} \mathrm{R}^{2}=0.999\right) ; 320 \mathrm{~nm}$ for t-resveratrol ( $\mathrm{LOD}=0.01 \mathrm{mg} \mathrm{L}^{-1} \mathrm{R}^{2}=0.999$ ), caffeic acid (LOD $\left.=0: 08 \mathrm{mg} \mathrm{L}^{-1} \mathrm{R}^{2}=0.998\right)$, cinnamic acid (LOD = $\left.0: 11 \mathrm{mg} \mathrm{L}^{-1} \mathrm{R}^{2}=0.999\right)$ ), $\mathrm{p}$-coumaric acid (LOD = 0:05 $\mathrm{mg} \mathrm{L}^{-1} \mathrm{R}^{2}=0.999$ ) and chlorogenic acid (LOD 
$\left.=0: 02 \mathrm{mg} \mathrm{L}^{-1} \mathrm{R}^{2}=0.998\right) ; 360 \mathrm{~nm}$ for the flavonols kaempferol ( $\mathrm{LOD}=0: 06 \mathrm{mg} \mathrm{\textrm {L } ^ { - 1 }} \mathrm{R}^{2}=0.998$ ), myricetin ( $L O D=0.01 \mathrm{mg} \mathrm{L}^{-1} \mathrm{R}^{2}=0.999$ ), quercetin $\left(\mathrm{LOD}=0.002 \mathrm{mg} \mathrm{L}^{-1} \mathrm{R}^{2}=0.999\right)$ rutin $(\mathrm{LOD}=0: 04$ $\left.\mathrm{mg} \mathrm{L}^{-1} \mathrm{R}^{2}=0.999\right)$ and isorhamnetin ( $\mathrm{LOD}=0.01$ $\mathrm{mg} \mathrm{L}^{-1} \mathrm{R}^{2}=0.998$ ); and 520 $\mathrm{nm}$ for the anthocyanins malvidin 3,5-diglucoside ( $\mathrm{LOD}=0: 06 \mathrm{mg} \mathrm{L}^{-1} \mathrm{R}^{2}=$ 0.999) Cyanidin 3,5-diglucoside ( $\mathrm{LOD}=0: 04 \mathrm{mg}$ L-1 R2 = 0.998), malvidin-3-glucoside (LOD = 0:03 $\left.\mathrm{mg} \mathrm{L}^{-1} \mathrm{R}^{2}=0.997\right)$ Cyanidin 3-glucoside (LOD = $0: 11 \mathrm{mg} \mathrm{L}^{-1} \mathrm{R}^{2}=0.998$ ) peonidin-3-glucoside (LOD $=0.01 \mathrm{mg} \mathrm{L}^{-1} \mathrm{R}^{2}=0.997$ ) delphinidin 3-glucoside ( $\left.\mathrm{LOD}=0: 09 \mathrm{mg} \mathrm{L}^{-1} \mathrm{R}^{2}=0.999\right)$ and 3-Pelargonidin glucoside ( $\left.\mathrm{LOD}=0: 04 \mathrm{mg} \mathrm{L}^{-1} \mathrm{R}^{2}=0.983\right)$. In the $\mathrm{FD}$, the photon excitation was carried out at $280 \mathrm{~nm}$ and the emission at $320 \mathrm{~nm}$ for (+) - catechins (LOD $\left.=0.01 \mathrm{mg} \mathrm{L}^{-1} \mathrm{R} 2=0.988\right)$, procyanidin $\mathrm{B} 2(\mathrm{LOD}=$ $\left.0.001 \mathrm{mg} \mathrm{L}^{-1} \mathrm{R}^{2}=0.983\right)$, procyanidin A2 $(\mathrm{LOD}=$ $0.003 \mathrm{mg} \mathrm{L}^{-1} \mathrm{R}^{2}=0.990$ ) and (_) - epicatechin (LOD $=0.01 \mathrm{mg} \mathrm{L}^{-1} \mathrm{R}^{2}=0.983$ ).

The used column was a Gemini-NX C18, $150 \times 4.60 \mathrm{~mm}$, with $3 \mathrm{uM}$ of internal particles, and the pre-column was a Gemini-NX C18, 4.0 x 3.0 $\mathrm{mm}$, both manufactured by Phenomenex ${ }^{\circledR}$. The oven temperature was maintained at $40^{\circ} \mathrm{C}$ and the volume of injection was $10 \mu \mathrm{L}$ (juice previously filtered through $0.45 \mu \mathrm{M}$ membrane; AllcromPhenomenex, USA) and the flow rate was $0.5 \mathrm{~mL}$ $\min ^{-1}$. The mobile phase consisted of $0.85 \%$ phosphoric acid solution (solvent A) and acetonitrile (solvent B). The gradient elution was: 0 min: $100 \%$ A; 10 min: $93 \%$ A and $\%$ B 7; 20 min: $90 \% \mathrm{~A}$ and $10 \%$ B; 30 min: $88 \%$ A and 12\% B; 40 min: $77 \%$ A and $33 \% \mathrm{~B} ; 45 \mathrm{~min}: 65 \% \mathrm{~A}$ and $35 \% \mathrm{~B}$ and $55 \mathrm{~min}$ : $100 \% \mathrm{~B}$

The determination of the antioxidant activity of the samples was performed by the DPPH (2,2-diphenyl-1-picryl-hydrazyl) scavenger method of antioxidants according to Rufino et al. (2007a). For purposes of comparison with literature results, the percentage of scavenging of free radicals (\%SRL) was calculated using the formula suggested by Duarte-Almeida et al. (2006): \% SRL $=(\mathrm{Ac}$ Am) x $100 / \mathrm{Ac}$, where 'Ac' is the control Abs and 'Am' is the sample Abs. In this parameter, high values indicate a higher antioxidant capacity of the studied sample.

The evaluation of the antioxidant activity of juices by $\beta$-carotene / linoleic acid system followed a protocol recommended by Rufino (2007b). The extract sample was obtained according to the methodology of Larrauri, Rupérez and SauraCalixto (1997). The results were expressed as the \% of protection against oxidation.
Data were collected from 10 wines produced in the south of Minas Gerais, State, Brazil, named as STBE (Syrah Red Wine from Boa Esperança), STTC (Syrah Red Wine from Três Corações) , STCO (Syrah Red Wine from Cordislândia), MECO (Merlot Red Wine from Cordislândia), CSCO (Cabernet Sauvignon red wine from Cordislândia) and CFCO (Cabernet Franc red wine from Cordislândia); Whites: SBBE (Sauvignon Blanc from Boa Esperança), SBCO (Sauvignon Blanc from Cordislândia) and CHCO (Chardonnay from Cordislândia); Rosé: SRBE (Syrah Rose From Boa Esperança). The obtained results for the studied variables were submitted to variance analysis (ANOVA) and compared by Tukey's at 5\% of probability.

\section{RESULTS AND DISCUSSION}

\section{Total phenolics and flavanols}

The mean values and standard deviations for the total phenolic content and flavanols are presented in Table 1.

The observed amounts for total phenolics presented significant differences among the evaluated samples. Phenolic values observed in red wines are in accordance to literature for wine produced in traditional regions of Brazil, such as the regions of the São Francisco Valley and at Rio Grande do Sul State, ranging from 1410.83 to $3718.70 \mathrm{mg} \mathrm{L}^{-1}$ (OLIVEIRA et al 2011) and the region of Santa Catarina State, with values ranging from 474.94 to $4060 \mathrm{mg} \mathrm{L}^{-1}$ (BRIGHENTI et al 2014; Santin et al 2009). The values found in this study are even greater than the wines from São Paulo State wines with values ranging from 965 to $1230 \mathrm{mg} \mathrm{L}^{-1}$ (CASTILHOS; BIANCHI, 2012). The values are also in accordance with the total phenolic content of wines from different world production varieties and regions, such as Croatia (GENERALIĆ et al., 2019) and Spain (CASTROSOBRINO et al., 2019). The concentration of phenolic compounds in grapes is influenced by the grape variety, by environmental and climatic conditions (GARRIDO; BORGES, 2013; HE et al., 2010).

According to Miele et al. (2014), the presence of these compounds in grapes depends on various factors, such as terroir, grape variety, rootstock, soil physicochemical characteristics, climate factors during the growing cycle (mainly during grape ripening) and the crop practices used in vineyards. The association of these factors can influence the presence, concentration, diversity and characteristics of the phenolic composition of grapes 
and wines. During the maceration and fermentation process, the phenolic compounds are extracted from grape berries and can influence wine characteristics (CASTRO-SOBRINO et al., 2019; TEIXEIRA et al., 2013). The final concentration of the phenolic compounds are related to oenological parameters (CASTRO-SOBRINO et al., 2019), which can vary according to the winery.

Regarding the total flavanol content (Table 1), highest values were observed in MECO wines for catechin $\left(5.93 \mathrm{mg} \mathrm{L}^{-1}\right)$ and STBE wines presented the highest values for epicatechin (3.73 $\mathrm{mg} \mathrm{\textrm {L } ^ { - 1 }}$ ), epicatechin gallate ( $\left.2.23 \mathrm{mg} \mathrm{L}^{-1}\right)$, epigallocatechin (11.90 $\left.\mathrm{mg} \mathrm{L}^{-1}\right)$ and procyanidin A2 (1.66 $\mathrm{mg} \mathrm{L}^{-1}$ ), and larger mean values of total flavanols $\left(35.54 \mathrm{mg} \mathrm{L}^{-1}\right)$. Wine samples were not different regarding the procyanidin B1 levels. The CFCO and STBE wines presented the higher procyanidin B2 contents, with no statistical difference, reaching values of 8.70 and 8.56 , respectively. Table 2 shows the contents of total phenolic and flavanols in white wines.

Table 1. Phenolic compounds and $L^{*}$ values for wines from Minas Gerais State, Brazil.

\begin{tabular}{|c|c|c|c|c|c|c|}
\hline \multicolumn{7}{|l|}{ Wine } \\
\hline & STBE & STTC & STCO & MECO & $\mathrm{CSCO}$ & $\mathrm{CFCO}$ \\
\hline \multicolumn{7}{|l|}{ Flavanols } \\
\hline$(+)$-Catechin & $2.93 \pm 0.05^{\mathrm{d}}$ & $4.26 \pm 0.05^{c}$ & $4.23 \pm 0.05^{\mathrm{c}}$ & $5.93 \pm 0.05^{\mathrm{a}}$ & $2.83 \pm 0.05^{\mathrm{d}}$ & $4.76 \pm 0.05^{\mathrm{b}}$ \\
\hline (-)-Epicatechin & $3.73 \pm 0.05^{\mathrm{a}}$ & $3.30 \pm 0.00^{\mathrm{b}}$ & $2.40 \pm 0.00^{\mathrm{d}}$ & $3.36 \pm 0.05^{b}$ & $1.80 \pm 0.00^{\mathrm{e}}$ & $2.53 \pm 0.05^{\mathrm{c}}$ \\
\hline (-)Epicatechin gallate & $2.23 \pm 0.45^{\mathrm{a}}$ & $1.46 \pm 0.12^{\mathrm{bc}}$ & c $1.66 \pm 0.15^{\mathrm{ab}}$ & b $\quad 1.46 \pm 0.21^{b c}$ & $0.66 \pm 0.12^{\mathrm{d}}$ & $0.73 \pm 0.40^{\mathrm{cd}}$ \\
\hline (-)Epigallocatechin & $11.90 \pm 0.17^{\mathrm{a}}$ & $\mathrm{a} \quad 5.50 \pm 0.53^{\mathrm{b}}$ & $5.33 \pm 0.29^{b}$ & $5.56 \pm 0.55^{\mathrm{b}}$ & $5.56 \pm 0.15^{\mathrm{b}}$ & $5.20 \pm 0.10^{\mathrm{b}}$ \\
\hline Procyanidin A2 & $1.66 \pm 0.05^{\mathrm{a}}$ & $0.70 \pm 0.00^{\mathrm{f}}$ & $1.10 \pm 0.00^{\mathrm{d}}$ & $1.30 \pm 0.00^{\mathrm{c}}$ & $1.53 \pm 0.05^{\mathrm{b}}$ & $1.00 \pm 0.00^{\mathrm{e}}$ \\
\hline Procyanidin B1 & $4.53 \pm 0.05^{\mathrm{a}}$ & $3.83 \pm 0.12^{\mathrm{a}}$ & $4.13 \pm 0.05^{\mathrm{a}}$ & $2.10 \pm 2.25^{\mathrm{a}}$ & $2.63 \pm 0.12^{\mathrm{a}}$ & $4.06 \pm 0.12^{\mathrm{a}}$ \\
\hline Procyanidin B2 & $8.56 \pm 0.05^{\mathrm{a}}$ & $2.23 \pm 0.05^{\mathrm{c}}$ & $6.46 \pm 0.05^{\mathrm{b}}$ & $3.26 \pm 1.79^{c}$ & $4.00 \pm 0.00^{\mathrm{c}}$ & $8.70 \pm 0.00^{\mathrm{a}}$ \\
\hline Total flavanols quantification & $35.54 \pm 0.87$ & $21.28 \pm 0.87$ & $25.31 \pm 0.59$ & $22.97 \pm 4.90$ & $19.01 \pm 0.49$ & $26.98 \pm 0.72$ \\
\hline \multicolumn{7}{|c|}{ 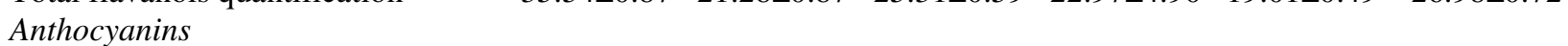 } \\
\hline Calistefin & $1.93 \pm 0.05^{\mathrm{b}}$ & $1.30 \pm 0.00^{\mathrm{d}}$ & $2.10 \pm 0.00^{\mathrm{a}}$ & a $\quad 1.03 \pm 0.05^{\mathrm{e}}$ & $1.66 \pm 0.05^{\mathrm{c}}$ & $1.56 \pm 0.05^{\mathrm{c}}$ \\
\hline Mirtilin & $0.90 \pm 0.00^{\mathrm{d}}$ & $1.00 \pm 0.00^{c}$ & $1,40 \pm 0.00^{\mathrm{b}}$ & b $\quad 0.80 \pm 0.00^{\mathrm{e}}$ & $1.60 \pm 0.00^{\mathrm{a}}$ & $1.00 \pm 0.00^{\mathrm{c}}$ \\
\hline Kuromanin & ND & $0.36 \pm 0.05^{\mathrm{a}}$ & ND & $0.30 \pm 0.00^{\mathrm{a}}$ & $0.30 \pm 0.00^{\mathrm{a}}$ & ND \\
\hline Peonidin 3-glucoside & $1.20 \pm 0.00^{\mathrm{a}}$ & $0.40 \pm 0.00^{\mathrm{c}}$ & $0.60 \pm 0.00^{\mathrm{b}}$ & b $\quad 0.40 \pm 0.00^{c}$ & $0.40 \pm 0.00^{\mathrm{c}}$ & $0.60 \pm 0.00^{\mathrm{b}}$ \\
\hline Petunidin & $0.43 \pm 0.05^{\mathrm{c}}$ & $0.40 \pm 0.00^{\mathrm{c}}$ & ND & $1.00 \pm 0.00^{\mathrm{a}}$ & $0.60 \pm 0.00^{\mathrm{b}}$ & ND \\
\hline Oenin & $19.83 \pm 0.05^{\mathrm{a}}$ & $6.20 \pm 0.10^{\mathrm{e}}$ & $10.76 \pm 0.05^{\mathrm{b}}$ & $5^{\mathrm{b}} \quad 4.06 \pm 0.05^{\mathrm{f}}$ & $9.03 \pm 0.05^{\mathrm{d}}$ & $9.30 \pm 0.00^{c}$ \\
\hline Total anthocyanin quantification & $24.29 \pm 0.15$ & $9.66 \pm 0.15$ & $14.86 \pm 0.05$ & $5 \quad 7.59 \pm 0.10$ & $13.59 \pm 0.10$ & $12.46 \pm 0.05$ \\
\hline \multicolumn{7}{|l|}{ Phenolic Acids } \\
\hline Gallic acid & $12.23 \pm 0.15^{\mathrm{e}}$ & $42.30 \pm 0.52^{\mathrm{a}}$ & $31.13 \pm 0.55^{\mathrm{c}}$ & $34.63 \pm 0.32^{b}$ & $25.20 \pm 0.17^{\mathrm{d}}$ & $30.46 \pm 0.15^{\mathrm{c}}$ \\
\hline Caffeic acid & $8.56 \pm 0.05^{\mathrm{a}}$ & $2.20 \pm 0.00^{c}$ & $6.46 \pm 0.05^{\mathrm{b}}$ & $3.26 \pm 1.78^{\mathrm{c}}$ & $4.00 \pm 0.00^{\mathrm{c}}$ & $8.70 \pm 0.00^{\mathrm{a}}$ \\
\hline Cinnamic acid & $0.60 \pm 0.00^{\mathrm{ab}}$ & ND & $0.60 \pm 0.00^{\mathrm{ab}}$ & $0.50 \pm 0.00^{\mathrm{bc}}$ & $0.40 \pm 0.05^{\mathrm{c}}$ & $0.70 \pm 0.00^{\mathrm{a}}$ \\
\hline Chlorogenic acid & $0.70 \pm 0.00^{\mathrm{e}}$ & $4.66 \pm 0.05^{\mathrm{a}}$ & $1.63 \pm 0.05^{\mathrm{d}}$ & $2.50 \pm 0.00^{\mathrm{c}}$ & $2.86 \pm 0.05^{\mathrm{b}}$ & $2.76 \pm 0.05^{\mathrm{b}}$ \\
\hline Syringic acid & $0.76 \pm 0.05^{\mathrm{ab}}$ & $0.76 \pm 0.23^{\mathrm{ab}}$ & $0.70 \pm 0.00^{\mathrm{ab}}$ & $0.96 \pm 0.05^{\mathrm{a}}$ & $0.46 \pm 0.11^{b}$ & $0.76 \pm 0.05^{\mathrm{ab}}$ \\
\hline Total phenolics acids quantificatio & n $22.85 \pm 0.25$ & $49.92 \pm 0.80$ & $40.52 \pm 0.65$ & $41.85 \pm 2.15$ & $32.92 \pm 0.38$ & $43.38 \pm 0.25$ \\
\hline Total monomeric anthocyanins ${ }^{t}$ & $123.19 \pm 4^{\mathrm{a}}$ & $102.07 \pm 7^{b}$ & $78.34 \pm 1^{\mathrm{c}}$ & $57.62 \pm 3^{\mathrm{d}}$ & $100.24 \pm 2^{b}$ & $73.98 \pm 8^{c}$ \\
\hline Total phenolic $\$$ & $2717 \pm 33^{\mathrm{b}}$ & $3009 \pm 46^{\mathrm{a}}$ & $2376 \pm 72^{c}$ & $2856 \pm 19^{\mathrm{ab}}$ & $2753 \pm 135^{b}$ & $2387 \pm 91^{\mathrm{c}}$ \\
\hline $\mathrm{L} *$ values & $11.17 \pm 0.00^{\mathrm{bc}}$ & $11.15 \pm 0.03^{\mathrm{c}}$ & $11.13 \pm 0.00^{\mathrm{c}}$ & $11.24 \pm 0.03^{\mathrm{a}}$ & $11.17 \pm 0.01^{\mathrm{bc}}$ & ${ }^{\mathrm{bc}} 11.22 \pm 0.01^{\mathrm{ab}}$ \\
\hline
\end{tabular}

Means followed by the same letters in the same line do not differ according to Tukey's test at 5\% probability. ND - not detected; STBE: Syrah (Boa Esperança); STTC: Syrah (Três Corações); STCO: Syrah (Cordislândia); MECO: Merlot (Cordislândia); CSCO: Cabernet Sauvignon (Cordislândia); CFCO: Cabernet Franc (Cordislândia); Total monomeric anthocyanins quantified by the technic of difference of $\mathrm{pH}$ and expressed as equivalent to cyanidin 3-glucoside; ${ }^{\S}$ Total phenolics measured with Folin-Ciocateau expressed as mg $\mathrm{L}^{-1}$ equivalent to gallic acid

No significant differences were observed for the total phenolic content among the studied white wines, with values ranging from $334.33 \mathrm{mg} \mathrm{L}^{-1}$ (SBCO) to $375.33 \mathrm{mg} \mathrm{L}^{-1}$ (SBBE). Oliveira et al (2011) studying white wines produced in northeast of Brazil, observed total phenolic values ranging from 278.73 to $548.42 \mathrm{mg} \mathrm{L}^{-1}$. Castilhos and Bianchi (2011) observed phenolic contents ranging from 178 to $367 \mathrm{mg} \mathrm{L}^{-1}$. Higher catechin $(3: 50 \mathrm{mg}$
$\left.\mathrm{L}^{-1}\right)$, epicatechin $\left(20.1 \mathrm{mg} \mathrm{L}^{-1}\right)$, epicatechin gallate (3.1 $\mathrm{mg} \mathrm{L}^{-1}$ ), mean values of total quantified flavanols (11.62 $\left.\mathrm{mg} \mathrm{L}^{-1}\right)$ and epigallocatechin $(1: 33$ $\mathrm{mg} \mathrm{L}^{-1}$ ) amounts were observed in $\mathrm{CHCO}$ wines. Regarding the A2 procyanidin contents, no statistical differences were observed between the wines, with contents ranging from 0.46 to $0.50 \mathrm{mg}$ $\mathrm{L}^{-1}$. Contents of $1.00 \mathrm{mg} \mathrm{L}^{-1}$ of procyanidin $\mathrm{B} 1$ were observed in SBBE and CHCO (1.00 $\left.\mathrm{mg} \mathrm{L}^{-1}\right)$ wines. 
Higher procyanidin $\mathrm{B} 2$ contents were observed in SBBE samples $\left(6.10 \mathrm{mg} \mathrm{L}^{-1}\right)$. On Table 3, is possible to observe the total phenolic content and flavanols of the evaluated rosé wine.

The total phenolic content observed was $632.33 \mathrm{mg}$ $\mathrm{L}^{-1}$ and among the flavanols, the compound procyanidin $\mathrm{B} 2$ was observed in higher values (15:33 $\left.\mathrm{mg} \mathrm{L}^{-1}\right)$, followed by epigallocatechin $(6.60$ $\left.\mathrm{mg} \mathrm{L^{-1 }}\right)$. The quantified total flavanol content to SRBE wine was $29.70 \mathrm{mg} \mathrm{L}^{-1}$. It is known that the degree of polymerization (DP) of flavanol compounds influences the perceived bitter and astringent sensations of flavanol-rich foods (GRIFFIN et al., 2019).

\section{Content of anthocyanins and $L *$ values of red wines}

Differences in the content of monomeric anthocyanins (Table 1) were observed for the evaluated red wines samples. Higher values were found in STBE (123.19 $\left.\mathrm{mg} \mathrm{L}^{-1}\right)$ wines, followed by STTC (102.07 $\left.\mathrm{mg} \mathrm{L}^{-1}\right)$ and CSCO (100.24 $\left.\mathrm{mg} \mathrm{L}^{-1}\right)$. Lower values for monomeric anthocyanins was observed in MECO wine, with contents of $57.62 \mathrm{mg}$ $\mathrm{L}^{-1}$. Oliveira et al (2011) found monomeric anthocyanin values ranging from 9.14 to $156.48 \mathrm{mg}$ $\mathrm{L}^{-1}$ in red wines produced in Brazil.

Regarding the anthocyanin content detected by HPLC in red wines, it was observed that the STCO wine showed higher calistefin values $(2.10$

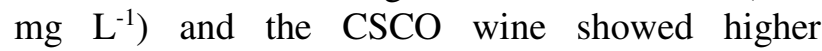
myricetin values $\left(1.60 \mathrm{mg} \mathrm{L}^{-1}\right)$. As for curomanin levels, STTC, MECO and CSCO showed the highest values, with no statistical differences, and values of $0.36,0.30$ and 0.30 , respectively. It is noteworthy that curomanin levels were not detected in STBE, STCO and CFCO wines. The higher petunidin contents for MECO samples (1.00), and the compound was not detected in STCO and CFCO wines. STBE wines presented higher levels of peonidin $\left(20.1 \mathrm{mg} \mathrm{L}^{-1}\right)$ and oenin $\left(19.83 \mathrm{mg} \mathrm{L}^{-1}\right)$, as well as higher anthocyanin values detected by HPLC (24.29 $\left.\mathrm{mg} \mathrm{L}^{-1}\right)$. Regarding the rose wine (Table 3), the oenin was observed in higher amounts (25.83 $\mathrm{mg} \mathrm{L}^{-1}$ ) when compared to other anthocyanins studied, and the total anthocyanins were quantified in the amount of $31.8 \mathrm{mg} \mathrm{L}^{-1}$.

Urvieta et al. (2018) observed that wines from grapes produced in different regions and altitudes of Argentina presented different amounts in anthocyanins content, with higher amounts associated to higher altitudes. Anthocyanins from plants are a group of important phenolic compounds which belong to the flavonoid family. They are the main pigments responsible for the color of red wines and are extracted from the wine must, being transformed during wine making and aging (LIU et al., 2019).

The $\mathrm{L}^{*}$ values of red wines are also shown in Table 1. Lower values were found in STCO (11.13) and STTC (11.15) wines, indicating darker wines than the other studied wines. Higher $\mathrm{L}^{*}$ values were observed in MECO wines (11.24), indicating a lighter color, that can be correlated with the anthocyanin content and was the lowest found among the studied samples $\left(57.62 \mathrm{mg} \mathrm{L}^{-1}\right)$. It is known that anthocyanins are directly related to grapes and the derived products. White wines (Table 2 ) showed no differences regarding the $L^{*}$ values, with average values of 35.28 (SBCO) and 37.47 (SBBE and CHCO). The rose wine (Table 3) presented $\mathrm{L}^{*}$ of 13.66 , values between the observed for this variable for red and white wines.

Table 2. Phenolic compounds and L* values for wines from Minas Gerais State, Brazil

\begin{tabular}{|c|c|c|c|}
\hline \multicolumn{4}{|l|}{ Wine } \\
\hline & SBBE & SBCO & $\mathrm{CHCO}$ \\
\hline \multicolumn{4}{|l|}{ Flavonols } \\
\hline (+)-Catechin & $0.60 \pm 0.00^{\mathrm{b}}$ & $0.56 \pm 0.05^{\mathrm{b}}$ & $3.50 \pm 0.00^{\mathrm{a}}$ \\
\hline (-)-Epicatechin & $0.60 \pm 0.17^{\mathrm{b}}$ & $0.73 \pm 0.05^{\mathrm{b}}$ & $1.20 \pm 0.00^{\mathrm{a}}$ \\
\hline (-)Epicatechin gallate & ND & ND & $1.03 \pm 0.05^{\mathrm{a}}$ \\
\hline (-)Epigallocatechin & ND & ND & $1.33 \pm 0.12^{\mathrm{a}}$ \\
\hline Procyanidin A2 & $0.50 \pm 0.00^{\mathrm{a}}$ & $0.46 \pm 0.05^{\mathrm{a}}$ & $0.50 \pm 0.00^{\mathrm{a}}$ \\
\hline Procyanidin B1 & $1.00 \pm 0.00^{\mathrm{a}}$ & $0.60 \pm 0.00^{\mathrm{b}}$ & $1.00 \pm 0.00^{\mathrm{a}}$ \\
\hline Procyanidin B2 & $6.10 \pm 0.10^{\mathrm{a}}$ & $0.50 \pm 0.00^{c}$ & $3.06 \pm 0.05^{\mathrm{b}}$ \\
\hline Total flavonols quantification & $8.80 \pm 0.27$ & $2.85 \pm 0.15$ & $11.62 \pm 0.22$ \\
\hline \multicolumn{4}{|l|}{ Flavonols } \\
\hline Quercetin & $0.60 \pm 0.00^{\mathrm{b}}$ & $0.93 \pm 0.05^{\mathrm{a}}$ & $0.36 \pm 0.05^{\mathrm{c}}$ \\
\hline Quercetin Piranoside & $0.30 \pm 0.00^{\mathrm{a}}$ & ND & $\mathrm{ND}$ \\
\hline \multicolumn{4}{|l|}{ Phenolic Acids } \\
\hline Gallic acid & ND & ND & $12.33 \pm 0.25^{\mathrm{a}}$ \\
\hline Caffeic acid & $6.10 \pm 0.10^{\mathrm{b}}$ & $7.10 \pm 0.00^{\mathrm{a}}$ & $3.06 \pm 0.05^{\mathrm{c}}$ \\
\hline
\end{tabular}




\begin{tabular}{llcc}
\hline Cinnamic acid & ND & $0.40 \pm 0.00^{\mathrm{b}}$ & $0.53 \pm 0.05^{\mathrm{a}}$ \\
Chlorogenic acid & $5.60 \pm 0.17^{\mathrm{b}}$ & $3.40 \pm 0.00^{\mathrm{c}}$ & $7.73 \pm 0.05^{\mathrm{a}}$ \\
Syringic acid & ND & ND & ND \\
Total phenolics acids quantification & $11.7 \pm 0.27$ & $10.90 \pm 0.00$ & $23.65 \pm 0.40$ \\
Resveratrol & ND & $0.40 \pm 0.00^{\mathrm{b}}$ & $0.50 \pm 0.00^{\mathrm{a}}$ \\
Total phenolic & $375.33 \pm 6^{\mathrm{a}}$ & $334.33 \pm 13^{\mathrm{a}}$ & $360.66 \pm 21^{\mathrm{a}}$ \\
$\mathrm{L}^{*}$ values & $37.47 \pm 0.58^{\mathrm{a}}$ & $35.28 \pm 2.13^{\mathrm{a}}$ & $37.47 \pm 2.40^{\mathrm{a}}$ \\
\hline
\end{tabular}

Means followed by the same letters in the same line do not differ according to Tukey's test at 5\% probability. ND - not detected; SBBE: Sauvignon Blanc (Boa Esperança); SBCO: Sauvignon Blanc (Cordislândia); CHCO: Chardonnay (Cordislândia); ${ }^{\mathrm{t} T o t a l ~ m o n o m e r i c ~}$ anthocyanins quantified by the technic of differential $\mathrm{pH}$ and expressed as cyanidin 3-glucoside equivalent; ${ }^{\S}$ Total phenolics measured with Folin-Ciocateau expressed as $\mathrm{mg} \mathrm{L}^{-1}$ gallic acid equivalent.

\section{Phenolic acids}

The observed contents of phenolic acids in the evaluated red wines are shown in Table 1 and ranged from 23.12 to $42.30 \mathrm{mg} \mathrm{L}^{-1}$ of gallic acid, 2.20 to $8.56 \mathrm{mg} \mathrm{L}^{-1}$ of caffeic acid, 0.40 to $0.70 \mathrm{mg}$ $\mathrm{L}^{-1}$ of cinnamic acid, 0.70 to $4.66 \mathrm{mg} \mathrm{L}^{-1}$ of chlorogenic acid and 0.46 to $0.96 \mathrm{mg} \mathrm{L}^{-1}$ of syringic acid. The total amounts of phenolic acids ranged from $22.85 \mathrm{mg} \mathrm{L}^{-1}$ (STBE) to $49.92 \mathrm{mg} \mathrm{L}^{-1}$ (STTC), and the higher gallic acid content $\left(42.30 \mathrm{mg} \mathrm{L}^{-1}\right)$ and chlorogenic acid (4.66 $\left.\mathrm{mg} \mathrm{L}^{-1}\right)$ were found for STTC wines. The CFCO and STBE samples showed the highest caffeic acid values, reaching 8.70 and 8.56

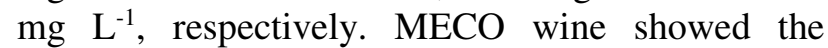
greatest syringic acid content, with values of 0.96 $\mathrm{mg} \mathrm{L}^{-1}$ and $\mathrm{CFCO}$ wines with the highest cinnamic acid contents $\left(0.70 \mathrm{mg} \mathrm{L}^{-1}\right)$.
Regarding the bioactive contents in white wines (Table 2), the wine $\mathrm{CHCO}$ presented the highest gallic acid $\left(12.33 \mathrm{mg} \mathrm{L}^{-1}\right)$, cinnamic acid (12.53 $\left.\mathrm{mg} \mathrm{L}^{-1}\right)$, chlorogenic acid $\left(7.73 \mathrm{mg} \mathrm{L}^{-1}\right)$ contents, and larger values of total phenolic acid (23.65 $\mathrm{mg} \mathrm{L}^{-1}$ ). Higher caffeic acid levels were found in SBCO wines $\left(7.10 \mathrm{mg} \mathrm{L}^{-1}\right)$. Syringic acid contents was detected in white wines. Among the phenolic acids, rose wine (Table 3), showed higher concentrations of caffeic acid $\left(15: 33 \mathrm{mg} \mathrm{L}^{-1}\right)$, followed by gallic acid $\left(12.73 \mathrm{mg} \mathrm{L}^{-1}\right)$, and the total phenolic acids content observed was $36.33 \mathrm{mg} \mathrm{L}^{-1}$. Padilha et al. (2017) observed a total amount of phenolic acids in Brazilian wine samples ranging from 41.30 to $228.7 \mathrm{mg} \mathrm{L}^{-1}$ and observed that caftaric acid was the main quantified, demonstrating that the terroir and the grape can strongly influence the total content of phenolic acids.

Table 3: Phenolic compounds and L* values of a rosé wine from Minas Gerais State, Brazil.

\begin{tabular}{lc}
\hline & Wine \\
\hline Flavanols & SRBE \\
(+)-Catechin & $2.20 \pm 0.00$ \\
(-)-Epicatechin & $1.43 \pm 0.12$ \\
(-)Epicatechin gallate & $1.70 \pm 0.44$ \\
(-)Epigallocatechin & $6.60 \pm 0.17$ \\
Procyanidin A2 & $0.77 \pm 0.12$ \\
Procyanidin B1 & $1.67 \pm 0.58$ \\
Procyanidin B2 & $15.33 \pm 0.06$ \\
Total flavonols quantification & $29.7 \pm 1.49$ \\
& \\
Anthocyanins & $3.10 \pm 0.00$ \\
Calistefin & $1.20 \pm 0.00$ \\
Mirtilin & $\mathrm{ND}$ \\
Kuromanin & $1.67 \pm 0.06$ \\
Peonidin 3-glucoside & $\mathrm{ND}$ \\
Petunidin & $25.83 \pm 0.05$ \\
Oenin & $31.8 \pm 0.11$ \\
Total anthocyanin quantification & \\
Phenolic Acids & $12.73 \pm 0.12$ \\
Gallic acid & $15.33 \pm 0.07$ \\
Caffeic acid & $0.70 \pm 0.00$ \\
Cinnamic acid & $7.57 \pm 0.21$ \\
Chlorogenic acid &
\end{tabular}




\begin{tabular}{lc}
\hline Syringic acid & ND \\
Total phenolics acids quantification & $36.33 \pm 0.40$ \\
Total monomeric anthocyanins & $38.72 \pm 0.98$ \\
Total phenolic & $632.33 \pm 42$ \\
L* values $^{*}$ & $13.66 \pm 0.24$ \\
$\%$ FRS & $13.48 \pm 0.30$ \\
$\%$ Protection & $28.36 \pm 1.37$ \\
\hline
\end{tabular}

SRBE: Syrah rose (Boa Esperança)

The values obtained for flavonols and in red wines are shown in Figure 1, with differences between the evaluated samples. The average values ranged from 0.36 to $0.76 \mathrm{mg} \mathrm{L}^{-1}$ to kaempferol, 0.76 to $3.93 \mathrm{mg} \mathrm{L}^{-1}$ to myricetin, 0.43 to $3.33 \mathrm{mg} \mathrm{L}^{-1}$ to quercetin, 3.4 to $6.2 \mathrm{mg} \mathrm{L}^{-1}$ to isohramnetin, 0.23 to $0.56 \mathrm{mg} \mathrm{L}^{-1}$ for rutin and 3.36 to $6.86 \mathrm{mg} \mathrm{L}^{-1}$ for quercetin pyranoside. The isohramnetin piranoside and quercetin were observed in samples, with considerable contents. Kaempferol and quercetin showed higher values in MECO wines, reaching $0.76 \mathrm{mg} \mathrm{L}^{-1}$ and $3.33 \mathrm{mg} \mathrm{L}^{-1}$, respectively. Quercetin piranoside was found in higher levels for MECO (6.86 $\left.\mathrm{mg} \mathrm{L}^{-1}\right)$ and CFCO (6:50 $\left.\mathrm{mg} \mathrm{L}^{-1}\right)$ wines. Myricetin has been found in higher amounts in the
STTC sample (3.93 $\left.\mathrm{mg} \mathrm{L}^{-1}\right)$. CSCO wines showed higher isohramnetin contents $\left(6.2 \mathrm{mg} \mathrm{L}^{-1}\right)$ and for rutin, higher values were observed in MECO $(0.50$ $\left.\mathrm{mg} \mathrm{L}^{-1}\right)$ and CFCO $\left(0.56 \mathrm{mg} \mathrm{L}^{-1}\right)$ wines. Oliveira et al., (2019) studying Brazilian tropical wines produced in different altitudes observed an effect of the altitude on the contents of kaempferol (1.1 to 3.5 $\mathrm{mg} \mathrm{\textrm {L } ^ { - 1 }}$ ), isorhamnetin (4.6 to $16.5 \mathrm{mg} \mathrm{L}^{-1}$ ) and quercetin (6.0 to $25.8 \mathrm{mg} \mathrm{L}^{-1}$ ) with higher values from wines produced with grapes from lower (350 m) altitude. The Minas Gerais State are characterized by regions with higher altitudes, which can explain the values in accordance to the observed by Oliveira et al. (2019) in wines from a region with $1100 \mathrm{~m}$ at Bahia, Brazil.

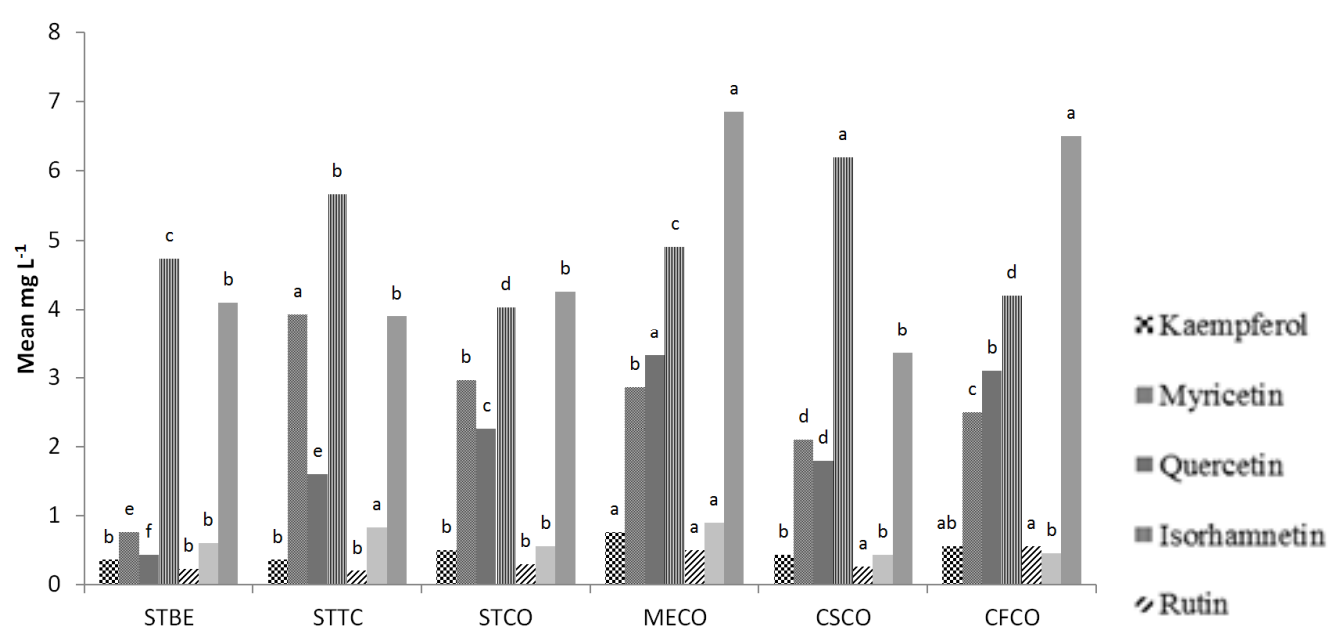

Figure 1. Mean values for flavonols and trans-resveratrol in wines produced in Minas Gerais, Brazil. STBE: Syrah (Boa Esperança); STTC: Syrah (Três Corações); STCO: Syrah (Cordislândia); MECO: Merlot (Cordislândia); CSCO: Cabernet Sauvignon (Cordislândia); CFCO: Cabernet Franc (Cordislândia).

According to the data presented in Table 2 for white wines, is possible to observe higher quercetin contents in SBCO wines $\left(0.93 \mathrm{mg} \mathrm{L}^{-1}\right)$ and quercetin piranoside contents were only observed in SBBE wines $\left(0.30 \mathrm{mg} \mathrm{L}^{-1}\right)$. Among the flavonols of the rosé wine (Table 4), the highest contents were observed for isohramnetin $\left(1.00 \mathrm{mg} \mathrm{L}^{-1}\right)$, followed by quercetin $\left(0.83 \mathrm{mg} \mathrm{L}^{-1}\right)$ and the values of flavonols achieved $3.3 \mathrm{mg} \mathrm{L}^{-1}$.

The higher levels of $\mathrm{t}$-resveratrol were observed in MECO $\left(0.90 \mathrm{mg} \mathrm{L}^{-1}\right)$ and STTC (0.83 $\mathrm{mg} \mathrm{L}^{-1}$ ) red wines. For the white wines (Table 2), the highest t-resveratrol values were observed in $\mathrm{CHCO}\left(0.50 \mathrm{mg} \mathrm{L}^{-1}\right)$ and the compound was not identified in SBBE wines. In the rose wine (Table 4), the t-resveratrol content found was $0.43 \mathrm{mg} \mathrm{L}^{-1}$. Caliari et al. (2014) analyzing classical and innovative varieties produced in Brazil, found $\mathrm{t}-$ resveratrol values ranging from 0.08 to $0.48 \mathrm{mg} \mathrm{L}^{-1}$. Meng et al (2012) analyzing wine produced in China found values ranging 0.08 to $0.70 \mathrm{mg} \mathrm{L}^{-1}$. Several studies demonstrated the beneficial effect of 
resveratrol in health, either by preventing a number of disorders or for a treatment of different diseases (TURNER et al, 2015; IDO et al, 2015; LIU et al, 2015; CHEN et al, 2014). Resveratrol (trans-3,4',5trihydroxystilbene) is a stilbene that can be found in a large number of plant products, including the skins and seeds of grapes and wines. There are scientific evidence has demonstrated that resveratrol can act with biological function preventing diseases (MARTINÉZ et al., 2018).

Table 4: Mean values for flavonols and trans-resveratrol in wine SRBE produced in Minas Gerais, Brazil.

\begin{tabular}{ll}
\hline \multicolumn{1}{c}{ Wine } & \\
\hline SRBE & \\
\hline Flavonols & $0.30 \pm 0.00$ \\
Kaempferol & $\mathrm{ND}$ \\
Myricetin & $0.83 \pm 0.06$ \\
Quercetin & $0.73 \pm 0.07$ \\
Quercetin Piranosideo & $1.00 \pm 0.00$ \\
Isorhamnetin & $0.17 \pm 0.06$ \\
Rutin & $3.03 \pm 0.19$ \\
Total flavonols quantification & \\
& $0.43 \pm 0.06$ \\
t-Resveratrol &
\end{tabular}

\section{Antioxidant activity of red wines}

In Figure 2 is possible to observe the antioxidant activity of red wines by the DPPH method.

The highest antioxidant activity (\% of free radicals scavenging - FRS) was observed for STTC wine $(75.37 \%)$, but not different from CSCO $(72.50 \%)$, values that can be correlated with the largest content of phenolics observed in wines as phenolic compounds (3009 $\mathrm{mg} \mathrm{L}^{-1}$ ), that present strong antioxidant activity. Lower values of FRS\% were found in STCO (64.04\%) and CFCO (65.15\%) wine samples. Regarding the antioxidant activity using the $\beta$-carotene/linoleic acid method, no statistical differences were observed for the different evaluated red wines. The average values in $\%$ of protection were STBE $(36.99 \%)$, STTC $(30,03 \%)$, STCO $(29.35 \%), \operatorname{MECO}(29.63 \%), \operatorname{CSCO}(32.16 \%)$ and CFCO (35.99\%).

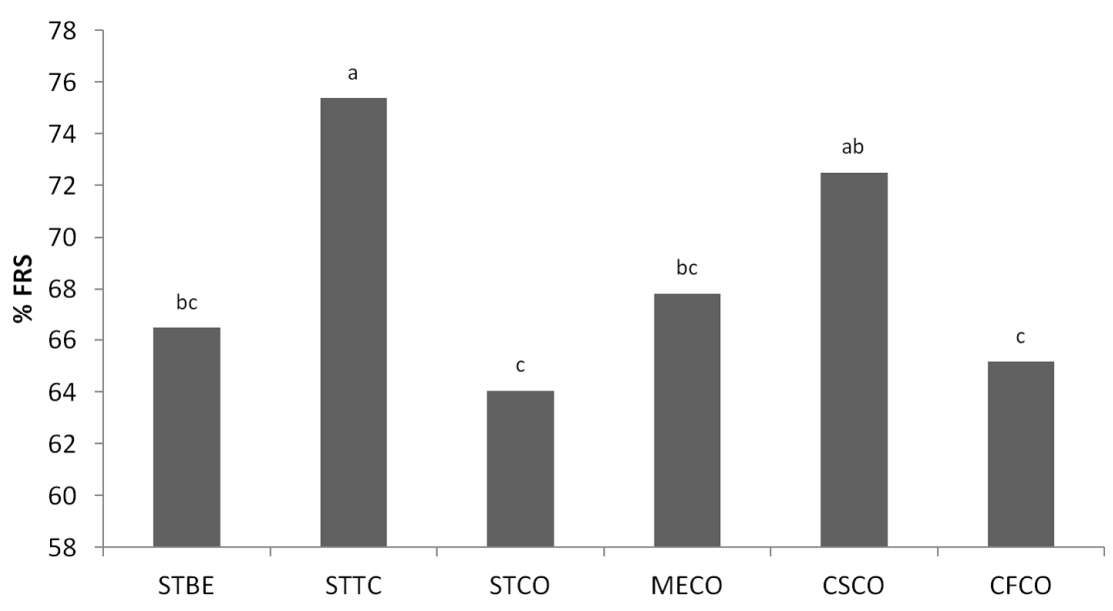

Figure 2. Mean values for antioxidant activity of wines produced in Minas Gerais, Brazil. STBE: Syrah (Boa Esperança); STTC: Syrah (Três Corações); STCO: Syrah (Cordislândia); MECO: Merlot (Cordislândia); CSCO: Cabernet Sauvignon (Cordislândia); CFCO: Cabernet Franc (Cordislândia).

Regarding the antioxidant activity of white wines (Table 2), no statistical differences were observed using both methods of evaluation. Using the DPPH method, the FRS\% of the samples were SBBE (5.68), SBCO (5.69) and CHCO (6.30). Using the $\beta$-carotene/linoleic acid method, the values observed were SBBE (23.75), SBCO (23.06) and $\mathrm{CHCO}$ (30.56) of free radical scavenging (FRS). The rose wine presented 13:48\% of FRS and $28.36 \%$ of protection against oxidation. Studies comparing the antioxidant activity of wines from emergent tropical regions, associated to the profile 
of bioactive phenolic compounds are scarce. The diversification in the phenolic profile of the grapes and wines of different regions can result in products with distinct antioxidant characteristics, which evidences the importance and the demand of studies regarding these chemical characteristics in wine produced regions.

The results suggest that not only the region of grape production play an important role in the development and content of compounds with antioxidant activity, but also the grape variety. Grapes contain a number of health-promoting compounds, like polyphenols, mainly in red varieties. It was expected, therefore, that red wines presented higher antioxidant activities, since red grapes present higher amounts of compounds associated to antioxidant capacity activities.

Antioxidants are compounds that have the ability to scavenge free radicals. Free radicals can cause oxidative damage which might build up over time and lead to degenerative diseases (ZUBIA \& DIZON, 2019). Activities above $70 \%$ of free scavenging radical has been considered a high anioxidant activity. So it could be concluded that the Cabernet Sauvignon wine produced in Três
Corações present this desirable activity, not differentiating, however, from Cabernet Sauvignon wines produced in Cordislândia.

\section{CONCLUSION}

Wines from the South of Minas Gerais State, Brazil, presented higher amounts of $\mathrm{t}$ resveratrol when compared to wines produced in traditional regions of the country. The wines studied presented significant contents of total phenolics, antocianins, flavonol, flavanols and phenolic acids, with the necessary bioactive characteristics to act as functional food for consumers and to allow the competition with traditional wine production regions and the consolidation of wines produced in the south of Minas Gerais State.

\section{ACKNOWLEDGMENTS}

The authors would like to thank CNPq, FAPEMIG and CAPES for the finnancial support and Embrapa/ Semiarid for the partnership during the project analysis.

RESUMO: Vinhos são conhecidos por seu alto teor de compostos bioativos, os quais podem ser influenciados pela região e clima de cultivo das uvas. Novas regiões de produção são normalmente desenvolvidas utilizando técnicas padrões estabelecidos em regiões produtoras tradicionais, mas é importante a caracterização do perfil do vinho obtido, que é diferente de acordo com o terroir e pode ser importante em futuras indicações geográficas. O objetivo do presente estudo foi avaliar a cor, capacidade antioxidante, teor de antocianinas e perfil de compostos fenólicos em vinhos produzidos no estado de Minas Gerais, Brazil. Vinhos foram produzidos em diferentes vinícolas do estafo utilizando as variedades Syrah, Merlot, Cabernet Sauvignon, Cabernet Franc (tintos), Chardonnay e Sauvignon Blanc (brancos) e vinhos Syrah (rose) roses dos municípios de Cordislândia, Boa Esperança e Três Corações, localizados no sul de Minas Gerais. Vinhos produzidos no estado de Minas Gerais apresentaram teores de t-resveraatrol, fenólicos totais, antocianinas, flavonóis, favanois e ácidos fenólicos consistentes com os observados em vinhos de outras regiões produtoras. No entanto, o terroir e a variedade de uva podem resultar em uma diferenciação de compostos observados em vinhos. Vinhos Syrah produzidos em Boa Esperança se destacaram com altos teores de antocianinas $(24.29 \mathrm{mg}$ $\mathrm{L}^{-1}$ ), ácidos fenólicos (123.19 $\mathrm{mg} \mathrm{L}^{-1}$ ) and flavanois (35.55 $\left.\mathrm{mg} \mathrm{L}^{-1}\right)$, quando comparados com vinhos da mesma variedade de outros municípios e os demais vinhos tintos avalaidos. Vinhos Sauvignon Blanc de Boa Esperança apresentaram altos tores de ácidos fenólicos e flavonoids totais, quando comparados com vinhos da mesma variedade produzidos em Cordislândia. Vinhos Chardonay apresentaram maiores teores de fenólicos totais quando comparados com outros vinhos brancos avaliados. Vinhos Rosé produzidos no Sul de Minas Gerais apresentaram teores de ácidos fenólicos de $36.33 \mathrm{mg} \mathrm{L}^{-1}$ e toeres de flavonois totais de $29.7 \mathrm{mg} \mathrm{L}^{-1}$. Maior atividade antioxidante pelo método do DPPH (\% de sequestro de radicais livres) foi observada em vinhos Syrah produzidos em Três Corações (75.37\%), não se diferenciando de vinhos Cabernet Sauvignon de Cordislândia $(72,50 \%)$, teores que podem ser correlacionados com o maiores tores de de fenólicos em vinhos, na forma de compostos fenólicos (3009 $\left.\mathrm{mg} \mathrm{L}^{-1}\right)$. Não foram observadas diferenças nos teores de atividade antioxidante em vinhos brancos. Os resultados indicam que os vinhos de Minas Gerais paresental características nutricionais e benéficas indicadas no consume, quando comparados com vinhos produzidos em tradicionais e diferentes regiões do Brasil e outros países.

PALAVRAS-CHAVE: Vitis vinifera. Compostos bioativos. Resveratrol. Qualidade. Vinhos brasileiros 


\section{REFERENCES}

ABE, L. T. Compostos fenólicos e capacidade antioxidante de cultivares de uvas Vitis labrusca L. e Vitis vinifera L. Ciência e Tecnologia de Alimentos, Campinas, v. 27, n. 2, p. 394-400, 2007.

https://doi.org/10.1590/S0101-20612007000200032

BRESCIANI, L.; CALANI, L.; BOCCHI, L.; DELUCCHI, F.; SAVI, M.; RAY, S.; BRIGHENTI, F.; STILLI D.; DEL RIO, D. Bioaccumulation of resveratrol metabolites in myocardial tissue is dose-time dependent and related to cardiac hemodynamics in diabetic rats. Nutrition, Metabolism \& Cardiovascular Diseases, Roma, v. 24, n. 1, p. 408-415, 2014. https://doi.org/10.1016/j.numecd.2013.09.008

BRIGHENTI, A. F.; SILVA, A. L.; BRIGHENTI, E.; PORRO, D.; STEFANINI, M. Desempenho vitícola de variedades autóctones italianas em condição de elevada altitude no Sul do Brasil, Pesquisa Agropecuária Brasileira, Brasília, v. 49, n. 6, p. 465-474, 2014. https://doi.org/10.1590/S0100-204X2014000600008

CALIARI, V.; BURIN, V. M.; ROSIER, J. P.; LUIZ, M. T. B. Aromatic profile of Brazilian sparkling wines produced with classical and innovative grape varieties. Food Research International, Burlington, v. 62, n. 1, p. 965-973, 2014. https://doi.org/10.1016/j.foodres.2014.05.013

CASTRO-SOBRINO, Laura et al. Impact of fungicides mepanipyrim and tetraconazole on phenolic profile and colour of Mencía red wines. Food Control, v. 98, p. 412-423, 2019.

https://doi.org/10.1016/j.foodcont.2018.11.035

CASTILHOS, M. B. M.; BIANCHI, V. L. D. Caracterização físico-química e sensorial de vinhos brancos da região noroeste de São Paulo, Holos, Natal, v. 4, n. 1, p. 148-158, 2011.

https://doi.org/10.15628/holos.2011.611

CASTILHOS, M. B. M.; BIANCHI, V. L. D. Vinhos tintos do noroeste paulista: relação entre os perfis físicoquímico e sensoria. Holos, Natal, v. 4, n. 1, p. 80-89, 2012. https://doi.org/10.15628/holos.2012.706

CHEN, Q., LIU, X.; ZHENG, P. Grape Seed Proanthocyanidins (GSPs) Inhibit the Growth of Cervical Cancer by Inducing Apoptosis Mediated by the Mitochondrial Pathway, Plos One, San Francisco, v. 9, n. 9, p. 1-12, 2014. https://doi.org/10.1371/journal.pone.0107045

CHEN, B.; XUE, J.; MENG, X.; SLUTZKY, J. L.; CALVERT, A. E.; CHICOINE, L. G. Resveratrol prevents hypoxia-induced arginase II expression and proliferation of human pulmonary artery smooth muscle cells via Akt-dependent signaling, American Journal of Lung Cellular and Molecular Physiology, v. 307, n. 1, p. 317-325, 2014. https://doi.org/10.1152/ajplung.00285.2013

CHOI, S.; LIM, T.; HWANG, M.K.; KIM, Y., KIM, J., KANG, N. J., JANG, T. S., PARK, J., YEOM, M. H.; LEE, K. W. (2013). Rutin inhibits B[a]PDE-induced cyclooxygenase-2 expression by targeting EGFR kinase activity, Biochemical Pharmacology, Kansas City, 86(1): 1468-1475.

https://doi.org/10.1016/j.bcp.2013.08.066

DECENDIT, A.; MAMANI-MATSUDA, M.; AUMONT, V.; WAFFO-TEGUO, P.; MOYNET , D.; BONIFACE, K.; RICHARD, E.; KRISA, S.; RAMBERT, J.; MERILLON, J. M.; MOSSALAYI, M. D. Malvidin-3-O- $\beta$ glucoside, major grape anthocyanin, inhibits human macrophage-derived inflammatory mediators and decreases clinical scores in arthritic rats, Biochemical Pharmacology, Kansas City, v. 86, n. 10, p. 1461-1467, 2013. https://doi.org/10.1016/j.bcp.2013.06.010

DEGÁSPARI, C. H.; WASZCZYNSKYJ, N. Propriedades antioxidantes de compostos fenólicos, Visão Acadêmica, Curitiba, v. 5, n. 1, p. 33-40, 2004. https://doi.org/10.5380/acd.v5i1.540 
DUARTE-ALMEIDA, J. M.; SANTOS, R. J.; GENOVESE, M. I.; LAJOLO, F. M. Avaliação da atividade antioxidante utilizando sistema $\beta$-caroteno/ácido linoléico e método de seqüestro de radicais DPPH. Ciência e Tecnologia de Alimentos, Campinas, v. 26, n. 2, p. 446-452, 2006. https://doi.org/10.1590/S010120612006000200031

EVANS, M.; WILSON, D.; GUTHRIE, N. A randomized, double blind, placebo controlled-pilot study to evaluate the effect of whole grape extract on antioxidant status and lipid profile. Journal of Functional Foods, Amsterdam, v. 7, n. 1, p. 680-691, 2014 https://doi.org/10.1016/j.jff.2013.12.017

FERNÁNDEZ-IGLESIAS, A., QUESADA, H., DÍAZ, S., PAJUELO, D., BLADÉ, C., AROLA, L. SALVADÓ, M. J., MULERO, M. Combination of grape seed proanthocyanidin extract and docosahexaenoic acid-rich oil increases the hepatic detoxification by GST mediated GSH conjugation in a lipidic postprandial state. Food Chemistry, Reading, v. 165, n. 1, p. 14-20, 2014. https://doi.org/10.1016/j.foodchem.2014.05.057

GARRIDO, J., BORGES, F. Wine and grape polyphenols - A chemical perspective. Food Research International, v. 54, p. 1844-1858, 2013. https://doi.org/10.1016/j.foodres.2013.08.002

GIUSTI, M. M., WROLSTAD, R. E. Characterization and measurement of anthocyanins by UV-Visible spectroscopy. Current protocols in food analytical chemistry. New York, USA: John Wiley and Sons Inc., 2001.

GRIFFIN, L.; DIAKO, C.; MILLER, L.; NEILSON, A.; ROSS, C.; STEWART, A. Preference for and Sensitivity to Flavanol Mean Degree of Polymerization in Model Wines Is Correlated with Body Composition, Current Developments in Nutrition, v. 3, n. 1, 2019. https://doi.org/10.1093/cdn/nzz031.P06$100-19$

HE, F., MU, L., YAN, G. L., LIANG, N. N., PAN, Q. H., WANG, J., DUAN, C. Q. Biosynthesis of anthocyanins and their regulation in colored grapes. Molecules, v. 15, p. 9057-9091, 2010. https://doi.org/10.3390/molecules15129057

HORT, M. A.; SCHULDT, E. Z.; BET, A. C.; DALBÓ, S.; SIQUEIRA, J. M.; IANSSEN, C.; ABATEPAULO, F.; SOUZA, H. P.; VELEIRINHO, B.; MARASCHIN, M.; RIBEIRO-DO-VALLE, R.M. Anti atherogenic effects of a phenol-rich fraction from brazilian red wine (Vitis labrusca L.) in hypercholesterolemic low-density lipoprotein receptor Knockout Mice. Journal of Medicinal Food, USA, v. 15, n. 10, p. 936-944, 2012. https://doi.org/10.1089/jmf.2011.0333

IDO, Y.; DURANTON, A.; LAN, F.; WEIKEL, K.A.; BRETON, L.; RUDERMAN, N.B. Resveratrol Prevents Oxidative Stress-Induced Senescence and Proliferative Dysfunction by Activating the AMPK-FOXO3 Cascade in Cultured Primary Human Keratinocytes. Plos One, San Francisco, v.10, n.2, p.1-18, 2015. https://doi.org/10.1371/journal.pone.0115341

JU, Y. et al. Anthocyanin accumulation and biosynthesis are modulated by regulated deficit irrigation in Cabernet Sauvignon (Vitis Vinifera L.) grapes and wines. Plant physiology and biochemistry, v. 135, p. 469479, 2019. https://doi.org/10.1016/j.plaphy.2018.11.013

LARRAURI, J. A.; RUPÉREZ, P.; SAURA-CALIXTO, F. Effect of drying temperature on the stabilitity of polyphenols and antioxidant activity of red grape pomace peels. Journal of Agricultural and Food Chemistry, Columbus, v. 45, n. 4, p. 1390-1393, 1997. https://doi.org/10.1021/jf960282f

LIU, Y.; W.; P.; D. Effect of resveratrol on blood pressure: A meta-analysis of randomized controlled trials. Clinical Nutrition, Luxemburgo, v. 34, n. 1, p. 27-34, 2015. https://doi.org/10.1016/j.clnu.2014.03.009

LIU, Y.; ZHANG, X.;; SHI, Y.; DUAN, C.; HE, F. Reaction kinetics of the acetaldehyde-mediated condensation between (-)-epicatechin and anthocyanins and their effects on the color in model wine solutions. Food Chemistry, v. 283, p. 315-323, 2019. https://doi.org/10.1016/j.foodchem.2018.12.135 
MAZUÉ, F.; DELMAS, D.; MURILLO, G.; SALEIRO, D.; LIMAGNE, E.; LATRUFFE, N. Differential protective effects of red wine polyphenol extracts (RWEs) on colon carcinogenesis. Food \& Function, v. 5, n. 1. p. 663-670, 2014. https://doi.org/10.1039/c3fo60417a

MENG, J.; XU, T.; QIN, M.; ZHUANG, X.; FANG, Y.; ZHANG, Z. Phenolic characterization of young wines made from spine grape (Vitis davidii Foex) grown in Chongyi County (China). Food Research International, Burlington, v. 49, n. 1, p. 664-671, 2012. https://doi.org/10.1016/j.foodres.2012.09.013

GENERALIĆ, I., SKRAČIĆ, Ž., KOKEZA, A.; SOLDO, B.; LJUBENKOV, I.; SKROZA, D. EFFECT of Winemaking On Phenolic Profile, Colour Components and Antioxidants In Crljenak Kaštelanski (sin. Zinfandel, Primitivo, Tribidrag) Wine." Journal of Food Science and Technology, v. 56, n. 4, p. 1841-1853, 2019. https://doi.org/10.1007/s13197-019-03638-4

MARTÍNEZ, L.; DIRAN, N.; MALOVINI, E. A Very Promising Molecule: Resveratrol, Induced Synthesis, and Health Benefits. In: Psychiatry and Neuroscience Update. Springer, Cham. p. 153-164, 2019. https://doi.org/10.1007/978-3-319-95360-1_13

MIELE, A.; FLORES, C. A.; ALBA, J. M. F.; BADALOTTI, C. B. Efeito do tipo de solo nos compostos fenólicos e na atividade antioxidante do vinho. Revista Brasileira de Viticultura e Enologia, Bento Gonçalves, v. 1, n. 6, p. 40-47, 2014.

NATIVIDADE, M. M. P.; CORREA, L. C.; SOUZA, S. V. C.; PEREIRA, G. E.; LIMA, L. C. O. Simultaneous analysis of 25 phenolic compounds in grape juice for HPLC: Method validation and characterization of Sao Francisco Valley samples. Microchemical Journal, Lake Charles, v. 110, p. 665-674, 2013. https://doi.org/10.1016/j.microc.2013.08.010

OLIVEIRA, L. C.; SOUZA, S. O.; MAMEDE, M. E. O. Avaliação das características físico-químicas e colorimétricas de vinhos finos de duas principais regiões vinícolas do Brasil. Revista Instituto Adolfo Lutz, São Paulo, v. 70, n. 2, p. 158-167, 2011.

OLIVEIRA, J. B. EGIPTO, R.; LAUREANO, O.; DE CASTRO, R.; PEREIRA, G. E.; RICARDO-DA-SILVA, J. M. Chemical and Sensorial Characterization of Tropical Syrah Wines Produced at Different Altitudes in Northeast of the Brazil. South African Journal of Enology and Viticulture, v. 40, n. 2, p. 1-15, 2019. https://doi.org/10.21548/40-2-3101

PADILHA, C. V. MISKINIS, G. A., DE SOUZA, M. E. A. O., PEREIRA, G. E., DE OLIVEIRA, D., BORDIGNON-LUIZ, M. T., DOS SANTOS LIMA, M. Rapid determination of flavonoids and phenolic acids in grape juices and wines by RP-HPLC/DAD: Method validation and characterization of commercial products of the new Brazilian varieties of grape. Food chemistry, v. 228, p. 106-115, 2017.

https://doi.org/10.1016/j.foodchem.2017.01.137

RUFINO, M. S. M.; ALVES, R. E.; BRITO. E. S.; MORAIS, S. M.; SAMPAIO, C. G.; PEREZ-JIMENEZ, J \& SAURA-CALIXTO, F. D. Metodologia científica: determinação da atividade antioxidante total em frutas pela captura do radical livre DPPH. Fortaleza: Embrapa, 4p. (Comunicado técnico, 127), 2007a.

RUFINO, M. S. M.; ALVES, R. E; BRITO, E. S.; FILHO, J. M \& MOREIRA, A. V. B. Metodologia científica: determinação da atividade antioxidante total em frutas no sistema $\beta$ caroteno - ácido linoléico. Fortaleza: Embrapa, 4p. (Comunicado técnico, 126), 2007b.

SAHPAZIDOU, D.; GEROMICHALOS, G. D.; STAGOS, D.;APOSTOLOU, A.; HAROUTOUNIAN, S. A.; TSATSAKIS, A. M.; TZANAKAKIS, G. N., HAYES, A. W., \& KOURETAS, D. Anticarcinogenic activity of polyphenolic extracts from grape stems against breast, colon, renal and thyroid cancer cells. Toxicology Letters, Würzburg, v. 230, p. 218-224, 2014. https://doi.org/10.1016/j.toxlet.2014.01.042 
SANTIN, N. C.; BORDIGNON, L. S.; MORAES, G. K. D. Polifenóis totais e outras características físicoquímicas de amostras de vinhos Merlot produzidos na região Meio-Oeste de Santa Catarina. Evidência, Campinas, v. 9, n. 1-2, p. 43-49, 2009.

SINGLETON, V. L.; ROSSI, J. A. Colorimetry of total phenolics with phosphomolybdic phosphotungstic acid reagents. American Journal of Enology and Viticulture, Davis, v. 16, p. 144-158, 1965.

TEIXEIRA, N.; CRUZ, L.; BRÁS, N.; MATEUS, N.; RAMOS, N. J. DE FREITAS, V. Structural features of copigmentation of oenin with different polyphenol copigments. Journal of Agricultural and Food

Chemistry, v. 61, n. 28, pp. 6942-6948, 2013. https://doi.org/10.1021/jf401174b

TURNER, R. S., THOMAS, R. G., CRAFT, S., DYCK, C. H. V., MINTZER, J., REYNOLDS, B. A., BREWER, J. B., RISSMAN, R. A., RAMAN, R., AISEN, P. S. A randomized, double-blind, placebocontrolled trial of resveratrol for Alzheimer disease. Neurology, Salt Lake City, v. 85, n. 16, p. 1383-1391, 2015. https://doi.org/10.1212/WNL.0000000000002035

URVIETA, R., BUSCEMA, F., BOTTINI, R., COSTE, B., FONTANA, A. Phenolic and sensory profiles discriminate geographical indications for Malbec wines from different regions of Mendoza, Argentina. Food Chemistry, v. 265, p. 120-127, 2018. https://doi.org/10.1016/j.foodchem.2018.05.083

VOLP, A. C. P.; RENHE, I. R. T.; BARRA, K.; STRINGUETA, T. C. Flavonoides antocianinas: características e propriedades na nutrição e saúde. Revista Brasileira de Nutrição Clínica, Porto Alegre, v. 3 , n. 2, p. 141-149, 2008.

ZUBIA, C. S.; DIZON, E. I. Physico-chemical, antioxidant and sensory properties of artificially-carbonated fruit wine blends. International Food Research Journal, v. 26, n. 1, 2019. 